\title{
Media Coverage of Environmental and Social Change in Northern Norway's Coastal Regions: Main Themes in National and International News
}

\author{
Bjørn P. Kaltenborn, ${ }^{1}$ Jenny F. Kaltenborn, ${ }^{2}$ Barbara B. Baczynska, ${ }^{3}$ Just Kornfeldt ${ }^{4}$ and Grete K. Hovelsrud ${ }^{3}$
}

\author{
(Received 21 June 2020; accepted in revised form 11 November 2020)
}

\begin{abstract}
Media are important agents in the shaping of northern images. Media coverage influences public perceptions and policy governing resource and societal development. But popular media often provide incomplete and skewed representations compared to the documentation provided by scientific literature and the range of activities and interests present in a region. We conducted a topic analysis of media coverage of environmental and social change in the Helgeland, Lofoten, and Vesterålen regions in northern Norway and Svalbard in the high Arctic during approximately 2014 to 2018. Our findings show that popular media collectively contribute to an image of expanding economic development based on natural resource exploitation. However, this narrative is incomplete in terms of the societal dynamics linked to natural resource development as documented in the scientific literature and somewhat biased towards climate change, oil and gas exploitation, tourism, and marine harvesting. Emergency preparedness issues and economic transitions are under-communicated, and we conclude that the popular media narrative only partly represents an alternative to the government policy discourse on northern issues.
\end{abstract}

Key words: northern Norway; media coverage; environmental and social change; Helgeland; Lofoten; Svalbard

RÉSUMÉ. Les médias jouent un rôle important dans le façonnement des images que les gens se font du Nord. La couverture médiatique influence les perceptions du public et les politiques régissant le développement des ressources et de la société. Cependant, il arrive souvent que les médias populaires fournissent des représentations incomplètes et biaisées comparativement à la documentation scientifique et aux divers activités et champs d'intérêt présents dans une région. Nous avons analysé les sujets couverts par les médias en matière de changement environnemental et social dans les régions de Helgeland, de Lofoten et de Vesterålen situées dans le nord de la Norvège et dans le Svalbard de l'Extrême-Arctique pendant la période allant de 2014 à 2018, environ. Selon nos constatations, les médias populaires contribuent collectivement à la formation d'une image de développement économique en expansion reposant sur l'exploitation des ressources naturelles. Toutefois, sur le plan de la dynamique sociale liée au développement des ressources naturelles, l'histoire est incomplète, comme en témoigne la documentation scientifique, et elle est quelque peu biaisée dans le sens du changement climatique, de l'exploitation pétrolière et gazière, du tourisme et des récoltes marines. Les questions entourant l'état de préparation en cas d'urgence et les transitions économiques ne font pas l'objet de communications suffisantes. Nous concluons que l'histoire racontée par les médias populaires ne représente qu'une éventualité partielle au discours politique et gouvernemental concernant les enjeux nordiques.

Mots clés : nord de la Norvège; couverture médiatique; changement environnemental et social; Helgeland; Lofoten; Svalbard

Traduit pour la revue Arctic par Nicole Giguère.

\section{INTRODUCTION}

In an increasingly connected and globalized world, the images of environmental challenges and governance needs are shaped and developed by public media (Holt and Barkemeyer, 2012). Many issues related to environmental change such as climate change, pollution of the world's seas, habitat degradation, and loss of biodiversity are considered global problems, while numerous other issues have relevance and importance limited to the local, regional, or national level. We like to think that, in the modern world, science holds the key position as the quality-controlled provider of the information on which environmental managers and policy developers base their decisions (Anderson, 2009; Antilla, 2010). That is hardly the case today, where a plethora of interests fights for attention and seeks to influence public opinion in desirable directions. To these interests, we can add the growing

\footnotetext{
${ }^{1}$ Corresponding author: Norwegian Institute for Nature Research, Fakkelgården, Storhove, 2624 Lillehammer, Norway; bjorn.kaltenborn@nina.no

2 Jázsai Mari utca 14, Pécs, 7623, Hungary

${ }^{3}$ Faculty of Social Sciences, Nord University, PO Box 1490, 8049, Bodø, Norway

${ }^{4}$ Handelshøyskolen BI, Nydalsveien 37, 0484 Oslo, Norway

(C) The Arctic Institute of North America
} 
tendency of public distrust in science seen in many parts of the world (Boykoff, 2008), the power games of ridiculing opponents in public space to undermine legitimacy, as well as the rapid expansion of fake news to create uncertainty (Lazer et al., 2018). The concept of a "sound knowledge base" becomes a fairly fuzzy idea.

As new opportunities develop through increased demand for consumptive as well as non-consumptive resources, important policy options and dilemmas must be considered. In the political struggles over development paths, managers and policy makers base their knowledge on multiple sources, often with different or questionable validity. In virtually all instances of environmental governance challenges, public communication plays a key role in shaping the public's perception, awareness, and judgement of preferred solutions (Olausson et al., 2009; Schmidt et al., 2013). Over the past few decades, environmental issues have fostered media discourses on all policy levels from the local to the global. A key feature in the current media development around environmental issues is the formidable proliferation of venues and channels and the way different types of media mix and interact (e.g., pieces of editor-controlled newspaper articles cited, paraphrased, or twisted in social media). Hence the distinction between different types of media is becoming increasingly blurred, and the initial providers and sources of information can be hard to track.

Media discourses and frames constitute what some researchers have called "cognitive windows" through which an issue gains meaning (Pan and Konsicki, 1993). A salient question is to what degree the meaning and understanding of an issue created by media are congruent with other discourses such as those created by policy and science. As Olausson (2009) argues, a key question is whether or not media offer any alternative frames or simply reflect and report the dominant policy context. In the example of climate change in Sweden, she concludes that the tight relationship between political elites and media results in media not producing any alternative discourses. Several other studies have come to a similar conclusion that media often fail to fulfill their role as the fourth state, since policy options of the nation-state seldom are examined in a critical and in-depth way by media (e.g., Herman and Chomsky, 1988; Bennett, 1994). This is a particularly important point in the Arctic context where most issues have multiscalar implications, involving priorities, interests, and concerns on several policy levels. For instance, quotas for coastal fishing or exploration for hydrocarbons can be carried out within established national legislation, but still create tensions if they are perceived internationally to impact the larger Arctic ecosystems reaching into international waters. Or tourism conducted over vast geographical space may generate much-needed local revenue in one area or nation while creating costs and impacts in another. Moreover, in the Arctic policies of all circumpolar Arctic nations, the basic priority is to secure domestic economic interests within a context of agreed-upon international collaboration. This priority creates a delicate policy game in which the "fourth state" can play a critical role in covering the dynamics and forces.

In this paper we analyze editor-controlled media coverage (i.e., formal news publications both paper- and internet-based) of social and environmental change in northern Norway, including Svalbard during a period roughly between 2014 and 2018. Through quantifying media coverage of a range of topics through this time period, we assess the patterns of coverage, potential biases, and skewed emphasis of topics. Our objective is to make a qualitative judgment of how well the media coverage of a selection of topics resonates with public policy as expressed by the key elements in the Norwegian government's High North and Arctic policies, as well as the main dimensions in the scientific literature on northern regions' challenges.

Northern coastal regions are "hot spots" for economic development as well as environmental conservation. Some authors have framed the northern regions as frontiers of vast opportunities and challenges (e.g., Noble et al., 2013), not the least due to climate change, developments in technology, new transportation routes, the global growth in demand for energy resources, and the tourism industry seeking ever-new destinations and attractions. Moreover, northern regions are gaining increased strategic importance since governance regimes, resource management, and economic development often contain geopolitical dimensions (Arbo et al., 2013; Kaltenborn et al., 2020a).

Norwegian High North policy rests formally on two documents. In 2014 the government formulated five prioritized "action areas" (Ministry of Foreign Affairs, 2014): international cooperation, commercial/ business development, knowledge, infrastructure, and environmental protection. These were later incorporated in full in the most recent version of the government's High North policy of 2020 (Ministry of Foreign Affairs, 2020). The document discusses overriding challenges of social, economic, and environmental sustainability. Prominent among these are a declining population base, the need for economic growth and value generation based on increased exploitation of natural resources, as well as climate change. The policy formulates four main goals: 1) maintaining peace, stability, and predictability, 2) integrating ecosystem-based management, international cooperation, and justice, 3) improving the basis for employment, and 4) creating value and welfare security. The broad policy picture is one of a resource-rich region with a large potential for economic growth with stable governance and minimal conflict. Albeit acknowledging a declining population base, the policy does not address challenging societal issues prevalent in many parts of northern Norway such as high unemployment levels (especially among young men), low levels of education, poorer health indicators than the national average, and centralization of public services in regional centres. Further, the policy does not address the threat of the corporate pelagic fishing industry to the coastal fisheries and local settlements that traditionally have provided $80 \%$ to $90 \%$ of the income from fishing (Aasjord 
and Hønneland, 2019). Moreover, the policy emphasis is on international cooperation and stability, but avoids any real discussion of the mounting geopolitical tensions and securitization of the Arctic.

Not unexpectedly, the scientific literature on social and environmental change in northern regions is diverse, somewhat fragmented, and does not coalesce into a coherent discourse. Depending on framing and approaches, different studies will inevitably produce different narratives. For instance, Padrtova (2019) studied how media portray the securitization of the Arctic and suggests four narrativesthe Arctic as resource base (economic security), as a nature reserve (environmental security), protection of natural interests (political and military security), and a region of traditional livelihood (societal security). Inspired by Padrtova (2019) and others, we suggest that the scientific literature broadly ascertains that northern coastal regions in Norway face significant challenges due to multiple drivers of environmental and social change. These include but are not limited to climate change and the need for adaptation (e.g., Ford and Furgal, 2009; Hovelsrud et al., 2011; HansenBauer et al., 2019), administrative reform into larger units, economic restructuring, rural depopulation and distancing of public services (e.g., Arbo et al., 2013; Kristoffersen and Dale, 2014; Dannevig and Hovelsrud, 2016; Kaltenborn et al., 2017), intense debate about natural resource exploitation options, and military securitization and geopolitical tensions (Haftendorn, 2011; Haley et al., 2011; Noble et al., 2013; Padrtova, 2019).

\section{APPROACH, METHODS, AND ANALYSIS}

Whereas media analysis makes use of different approaches, such as discourse analysis, narratives, and content or topic analysis, all approaches apply a frame (Matthes, 2009). In research on media coverage, a research frame is the organizing idea or principle that provides meaning (Pan and Kosicki, 1993) by selecting and focusing on certain elements of perceived reality. These elements form a desired type of communication by directing attention to specific issues or ways of defining a problem. Several authors have discussed how the framing of research on media performance often is under-communicated and taken for granted, hence, obscuring cultural, economic, and political factors (e.g., Trumbo, 1996; Matthes, 2009; Antilla, 2010). Ultimately, the way news is framed reflects power relationships since media directly and indirectly shape hegemonic meanings (Carragee and Roefs, 2004). Here, we understand framing to be both the assumptions and understandings that underpin the approach and the variables focused on, as well as a methodology whereby one examines the selection and importance of issues. The latter is commonly done by analyzing images, metaphors, stereotypes, actors, and messages (Entman, 1993; Reese, 2007). Frames can be generic and cross-culturally applicable such as the typology suggested by Semetko and Valkenburg
(2000) — conflict, human interest, economic consequences, morality and responsibility - or issue-specific derived from the analysis of contexts and expressions.

Framing does not happen in a social or political vacuum, but always reflects certain preferences and interests. Typical examples are social movements or stakeholders in a natural resource conflict in which different groups make claims to their specific understanding of an issue (e.g., Reed et al., 2009). The question of framing is important for two reasons in this study. First, newspapers tend to have their own styles expressed through linguistics, thematic focus, political orientation, as well as ideological conventions based on more or less taken-for-granted assumptions. The latter may not be obvious to the average reader. Elements of framing then are part of what we look for in this analysis. Second, as researchers, we compose a frame when we select what to analyze and choose topics and key words for the literature search. In that sense, there will always be a bias towards those communicative elements that we a priori identify as salient or interesting. Our assumption in this study is that a socio-ecological perspective is useful because we consider social and environmental factors to be intertwined and interdependent. This assumption has led us to select search words that cover environmental protection, environmental management, and drivers of change that are related to natural resource exploitation and economics one way or another.

Methodologically, this study is a topic analysis (Stieglitz et al., 2018) with some elements of content analysis (Vaismoradi et al., 2013). Our focus is mainly on identifying the themes of topics that have been covered over time. Content analysis in its proper form analyzes the patterns and properties of text in order to understand the structure of the text. However, we limit ourselves to identifying and categorizing the main themes covered by a range of news outlets in order to gain a broader picture of how local, regional, and international news media choose to cover northern issues. Here we interpret newspaper articles in order to categorize the message and meaning of each news outlet, but we do not link the individual articles to each other to elicit a structure or discourse that may have evolved over time.

We first defined the two main themes of interest as environmental management and environmental change and drivers of change. For the first theme, we used the following key search words: protected areas, oil and gas exploration and exploitation, tourism, biodiversity, cultural heritage, cultural landscapes, fishing, salmon, aquaculture, cod, shrimp fishing, ecosystems, and ecosystem-based management. For the second theme, we used the following key search words: climate change, pollution, oil and gas, sea food and aquaculture, tourism development, naturebased tourism, recreational homes, renewable energy, world heritage areas, shrub encroachment, and environmental policies and politics.

We then searched the internet for news outlets mainly limited to the $2014-18$ period, but with a few examples 
ranging back to $2010-11$, with a geographic scope covering the Helgeland, Lofoten, and Vesterålen regions in northern Norway and Svalbard in the Arctic. The searches targeted the local newspapers in the northern Norway region as well as a more open search to capture international postings about Svalbard issues. Finally, we conducted a discrete analysis of a single outlet, the internet-based High North News, based in northern Norway, but which has a circumpolar frame and focus. The purpose was to compare the perspective and coverage on northern issues, including the high Arctic, of an international news frame with that of local news agencies. We classified each news item into main concepts or categories and topics or key messages in the text. The coding was performed in two stages. First, three of the co-authors covered one geographic region each, reading all the news items and assessing to what extent the original set of key words fitted the particular context. Then we adjusted this initial typology and decided on the final typology for each of the three areas (northern Norway, Svalbard, circumpolar), as there were both similarities and differences across the three areas. Once the particular typologies were finalized, the three authors assigned each news item to the predefined categories of themes based on their best judgement. Finally, the lead author went through the complete coding list to check for errors and inconsistencies, which to some extent acted as a control for subjective biases since three persons were involved in the initial selection and interpretation of sources.

For the northern Norway region (Helgeland, Lofoten, and Vesterålen), we analyzed 62 media outlets. For Svalbard we retrieved 65 items, and for High North News, 82. Figure 1 shows an overview of the main themes in news media in the three geographic regions.

\section{RESULTS}

\section{Northern Norway}

The sources for this part of the analysis were seven different newspapers that were all accessed online: Lofotposten, Nordlys, Lofot-tidende, Bladet Vesterålen, Vesterålen Online, Helgelands Blad, and Helgelendingen. For this part of the analysis we identified nine categories of topics (Table 1). In order of descending number of news items, they rank: climate change, oil and gas exploration, environmental change, management, tourism and off-road motorized traffic (equal number of news items), economic development, environmental protection, and renewable energy. Climate change and oil and gas exploration issues clearly dominate in terms of volume. The categories were not defined a priori but developed and refined as we coded the news items. It is important to note that in some cases there can be a certain overlap between categories, and the assignment of individual news items to a category is a matter of interpretation. When we look at the key concepts in these categories, we find a great diversity of angles.

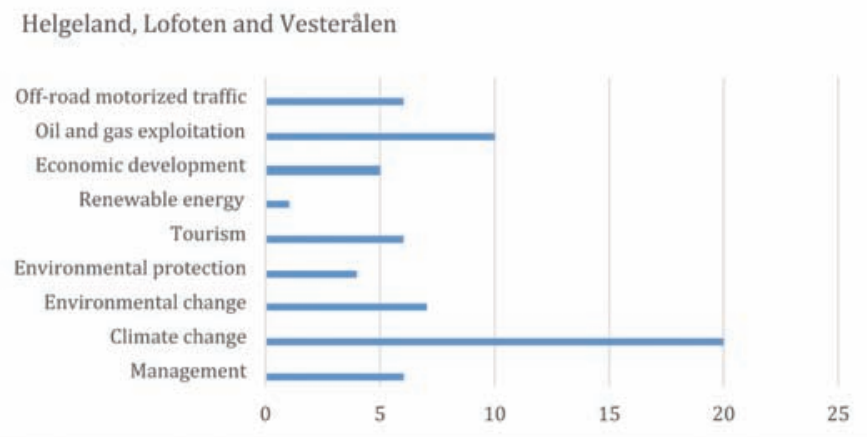

Svalbard

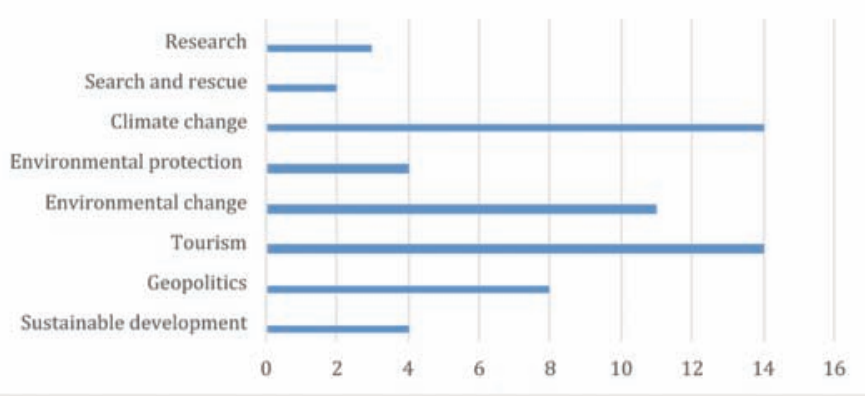

Circumpolar

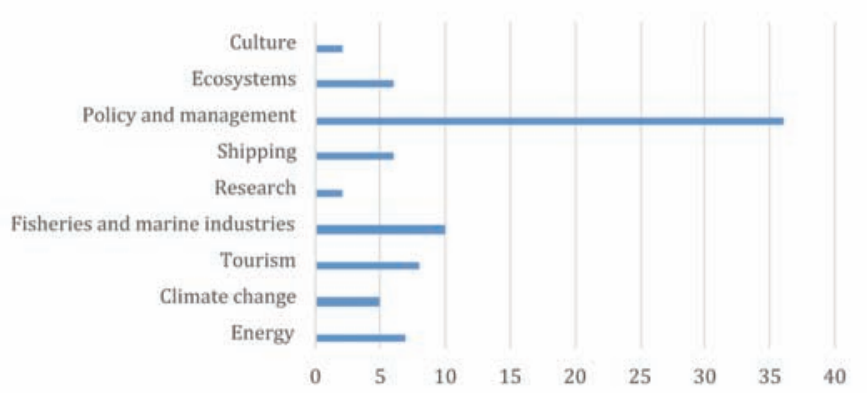

FIG. 1. Number of outlets per main theme for each region.

For climate change, social, political, and environmental factors are prominent. Several represent fairly imminent issues such as the need for rapid adaptation, improvements in infrastructure, but also long-term needs like planning, policy change, awareness raising, trust in politicians, and implications for future food security.

In the oil and gas category, environmental, political, and technological factors are discussed. There is considerable concern over the vulnerability of the marine environment and particularly the potential danger of oil spills to the fishing industry. There are also discussions of research needs, infrastructure development, and a need for better political coordination across sectors.

The coverage of environmental change also spans a wide range of issues from well-known and immediate, such as increased avalanches, changes in weather patterns, and terrestrial and biophysical changes to structural and institutional issues such as broader environmental debates, the need for institutional change, and changes to agriculture and food production (Table 1). 
The management news category spans both environmental and economic management. Key concepts and topics covered here include how to best manage marine ecosystems and food sources, and the monitoring and law enforcement of illegal fishing. News items also discussed the international role of Norway in coastal zone management, loss of biodiversity, and shrub encroachment of earlier agricultural lands due to land abandonment and the spread of Sitka spruce.

The key concepts of the tourism news items centre around organizational issues like the need for better cooperation among actors, development of infrastructure, visitor-host interactions, how to deal with increasing visitor populations, the need for better planning, as well as environmental challenges like pollution, terrain impacts, and littering.

Reports on off-road motorized traffic focused on legal and regulatory issues and tensions between local/municipal level management and more centralized governance, conflicts with other types of outdoor recreation activities, potential for accidents, impacts to wildlife, and the implementation of trails for recreational snowmobile use.

News items about economic development are diverse. The key concepts here focus on the seafood industry and on the potential for future sustainability, prospects for oil and gas exploration, how to deal with industries with high $\mathrm{CO}^{2}$ costs, and the implications of regionalization of advisory public institutions that support the commercial and private enterprise sectors.

Environmental protection is to some extent linked to and overlapped with environmental management, but we identify it here as a distinct category with key topics such as world heritage protection, new national parks in the coastal region, coastal zone management plans, and species protection. This category also includes news items on the positive linkages between environmental protection and the creation of new employment opportunities.

Finally, the topic of renewable energy received remarkably little media coverage in the time span we included in this study. One article however elaborated on progressive scenarios for windmill development and how this will be necessary in order to reach future EU targets (Table 1).

\section{Svalbard - The International Perspective}

For Svalbard, we examined news from 14 sources: Arctic Today, New York Times, Wall Street Journal, Financial Times, Russia Beyond, The Sun, Reuters, National Post, Japan Times, South China Morning Post, Moscow Times, Ice News, Berlingske, and The Diplomat. We assigned the international news coverage on Svalbard into eight categories, in descending order of number of items: climate change; tourism; environmental change; geopolitics; sustainable development; environmental protection; research, trade, and technology; and search and rescue (SAR) (Table 2).
In recent years, climate change and tourism questions have figured prominently in the international news coverage on Svalbard. Some of the climate-related messages focus on Svalbard specific issues like the flooding of the global seed vault due to thawing permafrost and food shortage for the local reindeer populations due to icing conditions on the tundra (locked pastures). Other news items deal with major impacts to the Svalbard environment, which are also experienced in other parts of the circumpolar Arctic such as warming weather, the thinning or absence of sea ice, and thawing permafrost. Several news postings also describe changes and impacts to Arctic communities and economies due to increasing cruise traffic as new waters open, as well as the increasing potential for extractive industries in the North (Table 2).

The coverage of tourism highlights the expanding northern lights tourism, the growth of expedition tourism, tourism as an economic activity overtaking former commercial sectors, increasing human-polar bear conflicts, concerns around increasing Arctic cruise traffic, and the global tourism potential in new and exotic products such as remoteness, cold, and the marginal ice zone.

The environmental change category covered postings about natural hazards and human safety, as well as ocean pollution and the potentially catastrophic effects of increased methane levels from melting permafrost.

The geopolitics category contains news items particularly on the Russian presence in Svalbard, official Norwegian responses to warranted and unwarranted activities by Russians, upgrading of Russian military basis in Franz Josef Land, and what some see as the new cold war in the Arctic. News stories also covered discussions on NATO's role in the Arctic and the need to show presence in Svalbard.

The sustainable development and environmental protection categories received approximately the same amount of coverage in terms of news items; there are some obvious linkages between the two, as well as linkages to some other categories. Sustainable development news items address future commercial opportunities, the closing of the coal mines, prospects for future livelihoods in the communities, and the current endangerment of the global seed vault by climate change effects. News on environmental protection spans across multiple items from general calls for more protected areas in the Arctic, concerns about the impacts from oil and gas exploration on Arctic fishing, aspects of the green shift in northern areas, to slightly more specific topics like impacts of black carbon on Arctic warming and increasing methane levels.

In the research, trade, and technology category, we found that news outlets addressed Russian-Chinese cooperation to advance industrial development of the Arctic, as well as China's interests in studying Arctic climate change, motivated by concerns over future long-term effects on environmental conditions and agriculture in China. Other news items reported on the large state subsidies to continue short-term coal mining operations in Svalbard and the 
TABLE 1. Categories and topics covered by local media in the Helgeland, Lofoten, and Vesterålen regions of northern Norway.

\begin{tabular}{|c|c|}
\hline Climate change (20) & $\begin{array}{l}\text { Impacts to infrastructure } \\
\text { Need for adaptation } \\
\text { Threats to human life and safety } \\
\text { Threats to biodiversity } \\
\text { Need for more responsive planning } \\
\text { International negotiations } \\
\text { Climate change links to poverty } \\
\text { Climate change policies } \\
\text { Reactions of non-governmental organizations (NGOs) to government policies } \\
\text { Increase in natural disasters } \\
\text { Extreme or "non-normal" weather } \\
\text { Melting of ice caps } \\
\text { Increasing sea levels } \\
\text { Basis for a green revolution } \\
\text { Younger generations engagement } \\
\text { Youth need to set high demands } \\
\text { Need for differentiated fuel prices between urban and rural area } \\
\text { Suggestions for various forms of public transport } \\
\text { Reduced snow cover and implications for winter sports } \\
\text { Tourism industry } \\
\text { Local identity } \\
\text { Trust in politicians and climate change policies } \\
\text { Changes in work and employment structures } \\
\text { Research } \\
\text { Awareness raising } \\
\text { Future reputations of regions depend on how climate change challenges are handled } \\
\text { Environmental tax on flying } \\
\text { Lack of climate change policies in land use planning at the local level } \\
\text { Food production and safety }\end{array}$ \\
\hline Oil and gas exploration (10) & $\begin{array}{l}\text { Skepticism towards environmental impact assessment not capturing the complexity and breadth of environmental issues } \\
\text { Uncertainty about environmental impacts from seismic activities in Lofoten-Vesterålen highly vulnerable marine } \\
\text { environments } \\
\text { Cold water coral reefs } \\
\text { Effect on whales } \\
\text { High level of research interests } \\
\text { Infrastructure development for shipping oil } \\
\text { Potential "oil harbour" in Bodø } \\
\text { Northward movement of the oil industry } \\
\text { Intense competition between Norwegian and foreign actors } \\
\text { Resource hot-spot in northern Norway } \\
\text { Statoil/Hydro fail to cooperate with the fishing industry } \\
\text { NGOs call for petroleum-free zones in a new management plan } \\
\text { Statements by local fishermen about how the riches of the marine environment are jeopardized by the oil and gas industry } \\
\text { Political divisions over questions about environmental impact assessments } \\
\text { Cod fisheries represent enormous values and traditions threatened by the petroleum industry } \\
\text { History of seismic sounding to detect oil reservoirs } \\
\text { Early use (1960s) of dynamite } \\
\text { Disagreements over impacts to and potential collapse of fish populations }\end{array}$ \\
\hline Environmental change (7) & $\begin{array}{l}\text { Environmental debates } \\
\text { Numerous natural disasters } \\
\text { Disagreement over human roles } \\
\text { Deadly algae } \\
\text { Seaweed contamination } \\
\text { Forest death } \\
\text { Projections for increased likelihood of rock avalanches and floods along the northern Norway coasts } \\
\text { Call for a new environmental award for institutions that stand out in handling environmental concerns and changes } \\
\text { Agriculture and food production need to be more concerned about lessening their impacts to biodiversity and environment in } \\
\quad \text { general } \\
\text { Regrowth of shrub and forest lands } \\
\text { Invasive species } \\
\text { Spread of Sitka spruce }\end{array}$ \\
\hline
\end{tabular}


158 • B.P. KALTENBORN et al.

TABLE 1. Categories and topics covered by local media in the Helgeland, Lofoten, and Vesterålen regions of northern Norway - continued:

\begin{tabular}{ll}
\hline \hline Main categories (no. of items) & Topics/key concepts \\
\hline \multirow{2}{*}{ Management (6) } & Need for monitoring and law enforcement of illegal fishing \\
& Shrub encroachment \\
& Loss of biodiversity \\
& Spread of Sitka spruce \\
& Endangered species \\
& Need for broader attention towards lesser known species \\
& Increasing rates of species loss \\
& Habitat degradation \\
& Need for more knowledge \\
& Marine and coastal food production \\
& Political statements that Norway should be at the frontline for knowledge about coastal resources \\
& Marine ecosystems \\
& Fisheries management \\
& Commercial management of raudåte (Calanus finmarchicus) \\
& Links between fish as a food source for seabirds \\
& Links between food availability and the reduction in seabird numbers.
\end{tabular}

Tourism (6)

Lack of adequate infrastructure

Visitor pressure

Environmental problems and impacts

Private-public partnerships

Impacts and disturbance to local communities

Need for better cooperation among actors

Protected areas give new economic opportunities in buffer zones

Increase in domestic tourism

Tourism patterns are affected by economic fluctuations

Problems and challenges with large-scale tourism

Terrain impacts

Littering

Pollution

Business sector invites large-scale tourism without absorbing the costs associated with visitor management and environmental impacts

Need for better planning

Tourism statistics

Off-road motorized traffic (6) Need for management regulations for off-road traffic

Local level/municipal management responsibility

Weak legislation

Concern over impacts to other forms of outdoor recreation and environment

Legislation contradicts research recommendations

Noise pollution

Higher risks of accidents with more liberal regulations

Impacts to nature experiences

Personal watercraft can impact biodiversity

Municipalities have not yet had time to properly consider pros and cons of new phenomena

Recreational organizations strongly oppose the liberalization and lack of legislation regulating watercraft use

Law enforcement

Tourism industry also strongly against unregulated use

Large potential conflicts with birds and wildlife

Newly established rentals of personal watercraft

Survey shows significant support for new snowmobile trails in a many municipalities

Ministry of Environment revokes permission to establish new snowmobile trail (Hattfjelldal)

Economic development (5) Growth in aquaculture

Goals of doubling in salmon production

Goals of achieving economic, social and environmental sustainability

Aquaculture as key factor in settlement along the coast

Agriculture

Regionalization of advisory institutions (Nordland, Troms, Finnmark)

Goals of increasing production

Revenues and recruitment to the seafood industry

$\mathrm{CO}^{2}$ compensation to industry that has long-term energy contracts with high $\mathrm{CO}^{2}$ costs

Unrealistic beliefs in the growth rate for the oil and gas industry in the North

Expansion of traditional fisheries due to favourable climate change

Food production

Norway should be at the forefront of knowledge production for sustainable use of marine resources

Fish has been an export commodity since year 1100

$95 \%$ of Norwegian sea food is exported 
TABLE 1. Categories and topics covered by local media in the Helgeland, Lofoten, and Vesterålen regions of northern Norway - continued:

\begin{tabular}{|c|c|}
\hline Main categories (no. of items) & Topics/key concepts \\
\hline Environmental protection (4) & $\begin{array}{l}\text { World heritage protection } \\
\text { National parks } \\
\text { Pressure from economic development } \\
\text { County-based protection plans (Helgeland) } \\
\text { New employment opportunities } \\
\text { Problems for resource-based industries } \\
\text { Land-use protection } \\
\text { Wise management and protection can provide large economic benefits for state } \\
\text { Protection of endangered species }\end{array}$ \\
\hline Renewable energy (1) & $\begin{array}{l}\text { Expectance of five-doubling of windmills by } 2020 \text { from current number of } 220 \text { to ca. } 1000 \\
\text { Norwegian Water Resources and Energy Directorate receives far too many poorly prepared plans for new windmills } \\
\text { More windmills are required to reach EU target of } 67.5 \% \text { of energy production by } 2020 \\
\text { Major impacts and conflicts linked to construction of windmills } \\
\text { Many complaints from municipalities to state-initiated plans }\end{array}$ \\
\hline
\end{tabular}

subsequent cleanup of sites and reclamation and restoration of localities.

Somewhat surprisingly, SAR topics in Svalbard and adjacent waters received little attention in international news media. The key themes were a Russian helicopter crash with eight fatalities, the evacuation of large parts of Longyearbyen due to avalanches, and extreme weather events straining the emergency preparedness capacities.

\section{Circumpolar Perspective: High North News}

High North News markets itself as a web-based independent newspaper located at the High North Center at Nord University in Bodø. It has a circumpolar perspective on the Arctic, but a particular focus on the Norwegian northern regions. We placed the news postings in nine categories, in descending order of number of items: policy and management; fisheries and marine industries; tourism; energy; shipping; ecosystems, biodiversity, and environmental change (equal number of items to shipping); climate change, research, and culture (the latter two equal numbers on news items) (Table 3 ).

The policy and management category is by far the largest topic in terms of number of news items during the time period we included in this study. It is diverse in terms of central concepts, which range from highly generic and supranational to local and specific. Examples of the first are postings discussing the need for responsible and sustainable management of the Arctic region as a whole, finding a balance between economic development and environmental protection and cross-border protection, and search and rescue operations, as well as the need for more circumpolar cooperation around tourism development and research. Examples of quite specific issues include controversies over Chinese hotel plans in Longyearbyen, concessions for commercial flights to Svalbard, and questions about future activities for the coal mining company in Longyearbyen when mines will be closed, and the somewhat controversial plans for new and expanded harbour facilities in Longyearbyen. This category also contains several pieces of news coverage on strategic and security issues, which address general as well as specific questions. For example, High North News actively discusses NATO's role in the Arctic, Russia's broader military and strategic interests in the Arctic, but also the controversy around the NATO Parliamentary Assembly in Longyearbyen in 2017, to which the Russians objected strongly.

The fisheries and marine industries category also reflects a strategic perspective. Several items report on the snow crab controversy in Svalbard waters (interpretation of the status and jurisdiction of this relatively new species to the area), EUs attempts to grant quotas for harvesting, and illegal fishing. There are also news post on the upgrading of the International Maritime Organization (IMO) Polar Code for shipping and the potential for a fish processing plant in Svalbard, a facility that could have both practical and strategic implications for the high Arctic fishing industry.

The tourism coverage addresses the long-term discussions about the status of the Longyearbyen airport, and how downgrading the status of the airport from international to domestic is a key function for controlling the visitor influx to Svalbard. Other items cover tourism safety, the debate on what should be an ideal mix of visitors to the archipelago in the future, and the potential of the Svea mining facility for future tourism in a post-mining future.

The energy topic contains reports on how to supply Svalbard with energy in the future when the coal-fired power plant shuts down, the closure of the last mines, job security when an economic pillar is discontinued, the international pressure to abolish coal mining, and the implications of the declining Russian mining activity for their presence in Svalbard.

Shipping is increasing in the Arctic and the High News coverage on this topic is largely concerned with the challenges of expanding traffic as climate change allows ships to travel more freely in previously ice-covered waters. This category includes items on search and rescue, upgrading the Polar Code with stricter technical and safety requirements for new vessels as well as older ships, future bans on waste and sewage disposal in waters inside the territorial limit, and the need for increased monitoring. 
$160 \bullet$ B.P. KALTENBORN et al.

TABLE 2. Categories and topics covered by the international media about Svalbard.

Main categories (no. of items)

Climate change (14)

Tourism (14)

Environmental change (11)

Geopolitics (8)

Sustainable development (4)

Environmental protection (4)
Topics/key concepts

Flooding of global seed vault

Impacts on reindeer from global warming (reduced weights due to increasing rain and icing of habitat)

Warming winters

Thinning of sea ice

Thawing of permafrost

More avalanches

Scenarios of significantly rising temperatures

Warming of Arctic could bring colder temperatures to Europe- -Warm Arctic, Cold Continent"

Cruise ships in formerly isolated, icebound regions

Fear of large-scale accidents in fragile areas

The need to limit size of vessels and bans on crude oil as fuels

Fear of impacts on Arctic communities due to increased cruise traffic

New economic opportunities - "cold rush"

Effect of melting ice and permafrost on cruises, oil and gas exploitation, and mining

Indigenous dog sledding hindered by thaw

Potential extinction of polar bears

Increasing amounts of plastic waste ending up in Arctic regions

Unusual weather

Record heat

Northern lights tourism

Total solar eclipse

Ghost town tourism

Final frontier

Tourism superseding former industry

Environmental concerns over increasing cruise traffic and larger ships

Exotic aspect of the dark, polar winter

Hurtigruten largest tour operator in Svalbard

Polar bears

Icebergs

Expedition cruises

Svalbard as a "global hot destination"

References to Svalbard in Lonely Planet guides

Polar bear conflicts and more shooting of bears

Survival of polar bear attack

Avalanche hazard-human fatality

High methane levels under seabed

Potential hazards

Ocean pollution

Plastic pollution

New cold war

Unwarranted Russian visits in Svalbard

Norwegian response

Russian response to Norwegian protests to Russian visits

Russian military base in Frantz Josef Land

NATO's role in the Arctic and the need to show presence in Svalbard

Future commercial opportunities

Closing of mines

Faith in future of settlements

Global seed vault and "Doomsday" vault

Concern for protection of the Arctic

Black carbon

Green shift

Arctic warming

High methane levels

Call for ban on heavy oil use in Svalbard Cleanup of Soviet pollution 
TABLE 2. Categories and topics covered by the international media about Svalbard - continued:

\begin{tabular}{|c|c|}
\hline Main categories (no. of items) & Topics/key concepts \\
\hline Research, trade, and technology (3) & $\begin{array}{l}\text { Communication technology } \\
\text { Connectivity } \\
\text { Mothballing the last (productive) mines } \\
\text { Loss of money } \\
500 \text { million kroner in state subsidies to continue (short-term) operations } \\
\text { Mining historically cornerstone activity, important for upholding settlements in Svalbard } \\
\text { Russian-Chinese polar Engineering and Research Centre } \\
\text { Engage in studies intended to promote industrial development of the Arctic China's interest in studying climate in the } \\
\text { Arctic to assess effects on the country's environmental and economic activities } \\
\text { Arctic climate has negative effects on China's food security; increases flooding and affects agriculture } \\
\text { China works on three fronts to promote its interest in the Arctic: participation in international economic cooperation, joint } \\
\quad \text { research projects, and promoting its own expertise to contribute to global changes in the Arctic }\end{array}$ \\
\hline Search and rescue (SAR) (2) & $\begin{array}{l}\text { Russian helicopter crash with eight fatalities } \\
\text { Free economic zone } \\
\text { Evacuation of Longyearbyen due to avalanche hazard when two people were killed } \\
\text { Extreme weather } \\
\text { Search and rescue dogs } \\
10 \text { buildings hit by avalanche } \\
\text { Worst winter storm in Svalbard in } 30 \text { years, people brought to local hospital, many still unaccounted for }\end{array}$ \\
\hline
\end{tabular}

Like the shipping category, the ecosystems, biodiversity, and environmental change category contains relatively few items. The focus here is on pollution and the formidable task of cleaning up and environmental restoration after coal mining, negative effects of climate change, melting permafrost, preparedness for rabies outbreaks in Svalbard, and polar bear monitoring as human-bear encounters are increasing due to less ice in the Arctic waters.

There is, as in many of the other categories described here, a certain overlap between the ecosystem category and the climate change category. The latter also appears to be of limited interest to High North News. The few items we identified here deal with the interdependencies between Asia and the Arctic with respect to how changing conditions in the high North can have global implications (an issue mostly absent or ignored in other Norwegian media), decreasing ice cover, and public relations measures to raise awareness about climate change.

Finally, the topics of research and culture have received very little attention from High North News. The few items identified here report on Arctic perspectives on climate science, the need for research cooperation across disciplines, nations, and ideologies, as well as among artists and other actors in Svalbard (Table 3).

\section{DISCUSSION}

In this study we analyzed news postings from publications on the local, regional, national, and international level. These publications span from local newspapers with $10-15$ employees and limited resources to large international newspapers with substantive budgets and capabilities to cover wide-ranging issues. Given this diversity, funding structures include partial government subsidies, advertising revenues, as well as entirely private corporations, and differing political orientations and ownership. Hence, the framing and focus of themes vary across the relatively large number of outlets included in this study. All the newspapers covered here are to some extent available in digital format, while the bulk also maintain paper versions. Readership naturally spans a huge range from a few thousand for some of the local papers to potentially millions for the international publications.

We used the same search words to identify news items related to natural resource exploitation, economic development, and environmental management for the target areas of Helgeland, Lofoten, and Vesterålen in northern Norway and Svalbard. However, because of differences in media coverage, we developed somewhat different categories of topics for these areas.

We again caution against definitive conclusions, since our framing of the study through the particular selection of search words implies biases in perspective and interpretation. Our selection of time period of the news streams and the specific newspapers and internet sites accessed may also have resulted in confounding variables with a potential overrepresentation of some topics and neglect of others. It could well be for instance that if we had applied a specific public health, industry development, or domestic security perspective, we might have found representations of other or more diverse links to the natural resource base. Although beyond the scope of this study, we recommend that future research on media coverage of northern issues considers other drivers of change than the ones we have focused on here.

Although there are differences in how media in different regions have emphasized the relative importance of topics and extent of coverage, climate change, tourism, oil and gas exploration, and marine harvesting are at the forefront of attention. The media coverage of the northern Norway region reflects topics that have created significant political disagreement during recent years such as the heated debate over hydrocarbon exploration versus fishing and tourism 
TABLE 3. Categories and topics covered by the circumpolar High North News.

\begin{tabular}{|c|c|}
\hline Policy and management (36) & $\begin{array}{l}\text { EU/Norway dispute over snow crab licenses } \\
\text { Policy implications for other areas of resource harvesting and management } \\
\text { Concepts for a responsible future for the Arctic-how to strike a balance between economic development and } \\
\text { environmental conservation } \\
\text { NATO Parliamentary Assembly concerns about effects of global warming triggers Russian objections } \\
\text { Russian perspectives on NATO activities in the Arctic } \\
\text { High-level meetings between Russia and Norway to discuss Arctic issues } \\
\text { Norway's High North Strategy } \\
\text { Problems with organization of the emergency phone number system in Longyearbyen (SAR topic) } \\
\text { Russia-Norway cooperation to build a fish-processing plant in Svalbard } \\
\text { More cooperation around tourism } \\
\text { Science and logistics in polar areas } \\
\text { Norwegian Parliament intentions to have government agencies locate distance-dependent jobs in Svalbard supported by } \\
\quad \text { Foreign and Defence Committee with focus on research, education, tourism, and other business activities } \\
\text { Claims of a lack of openness in public discussions } \\
\text { Developments in Russia's politics and military strategies may affect Svalbard } \\
\text { Investment strategies for business and industry in Svalbard } \\
\text { Lack of clear direction for Store Norske } \\
\text { Comments on the latest Svalbard white paper } \\
\text { Rejection of permits for Finnair flights to Longyearbyen } \\
\text { Polish "Go Arctic" campaign } \\
\text { Establishment of an Arctic Security Centre at the United Nations International School } \\
\text { Barents Protected Area Network call for cross-border protection of Arctic nature } \\
\text { Right-wing concern over loss of jobs due to decline in coal mining } \\
\text { American senators in Svalbard to discuss defense and security in the High North } \\
\text { Socioeconomic development should be on the forefront of Arctic development } \\
\text { Plans for new harbour facilities in Longyearbyen } \\
\text { Chinese plans for hotel development in Longyearbyen } \\
\text { Ideas for Svalbard as the capital of the Arctic in the future }\end{array}$ \\
\hline
\end{tabular}

Fisheries and marine industries (10) The potential for Svalbard to become self-sufficient with fish

Trial of Latvian vessel for illegal fishing of snow crab

Debate over the status and jurisdiction of snow crab

Russian opposition to Norwegian interpretation of treaty on fishing rights

Dispute over EU allocation of quotas for snow crab

The potential for fish processing facilities in Svalbard

Concern over climate change effects on polar cod production

Tourism (8)

Consequences for tourism of the downgrading of Longyearbyen airport from international to national airport

Discussions about optimal tourism mix in Longyearbyen

Relations with Longyearbyen residents Spitsbergen marathon

Transition of Svea town from mining to tourism facility

Plans for Arctic Race (cycling) leg in Svalbard

Tourism information about safe travels in Svalbard

Energy (7)

Alternative energy discussions on Svalbard

Prohibitive costs of electricity from mainland

Job security in the coal mining industry

Coal mining

Closure of Svea mine

Strategic aspects of demolishing coal mining industry

Financial costs and concerns of discontinuing coal mining in Svalbard

Decrease in Russian coal mining

UN call to discontinue coal mining in Svalbard as incompatible with climate change mitigation goals

Shipping (6)

Ecosystems, biodiversity, and environmental change (6)
New challenges for management, search and rescue, and people in Svalbard due to increased shipping in the Arctic Announcement of future ban on waste and sewage disposal from ships within 12 nautical miles of Norwegian and Svalbard coasts

Expansion of Hurtigruten's Arctic sailing network to the Northwest Passage and Murmansk

Monitoring of shipping and problems with polar bears at the signal stations

Transpolar one-year ice drift in the Arctic Ocean with small expeditionary vessel IMO's new Polar Code with stricter rules and implications for older ships

Pollution and cleanup after coal mining

Large consensus on negative effects of climate change on biodiversity

Melting permafrost and problems with seed vault

Preparedness for rabies outbreaks in Svalbard

Polar bear monitoring - concern about climate change effects and problems with Russian cooperation 
TABLE 3. Categories and topics covered by the circumpolar High North News - continued:

\begin{tabular}{|c|c|}
\hline Main categories (no. of items) & Topics/key concepts \\
\hline Climate change (5) & $\begin{array}{l}\text { Interdependencies between Asia and the Arctic in climate change issues } \\
\text { Challenges with seed vault in Svalbard and thawing permafrost } \\
\text { Polar bear cartoon to raise awareness about climate change } \\
\text { Record low ice cover in } 2017 \text { (lowest in } 38 \text { years) }\end{array}$ \\
\hline Research (2) & $\begin{array}{l}\text { Research meetings in Svalbard to decide on knowledge needs and cooperation in the future (stressing cooperation across } \\
\text { disciplines, nations, ideologies, institutions) } \\
\text { Artistic perspectives on climate science }\end{array}$ \\
\hline Culture (2) & $\begin{array}{l}\text { Arctic Action performance festival-cooperation between artists and other actors in Svalbard } \\
\text { Plans for a new foundation to develop arts and culture in Svalbard }\end{array}$ \\
\hline
\end{tabular}

and, to some extent, environmental change (Misund and Olsen, 2013; Kristoffersen and Dale, 2014).

The Svalbard context mirrors an increasingly difficult emergency preparedness situation. This is a consequence of rapid climate change and economic restructuring due to the abolition of coal mining and transition to a community to be sustained by research, education and tourism, as well as policies carefully balancing the geopolitical ramifications of the Svalbard Treaty (Grydehøj, 2014; Kaltenborn et al., 2020a). Interestingly, whereas international news media to a minimal extent forward views on the geopolitical, strategic and security aspects of Svalbard, the High North News portfolio carries a strong emphasis on policy, management, and strategic aspects of Svalbard.

Norway's official high North policies are only partly reflected in the media coverage of social, economic, and environmental change identified here. There is relatively extensive coverage on various aspects of economic development based on natural resource exploitation. But whereas the policy documents go to great lengths to highlight the potential for employment and value creation, the media develops a narrative mixed with challenges, uncertainties, and opportunities. The policy history has for decades maintained an emphasis on peace, stability, international justice, value creation based on natural resources and welfare, and this message is reinforced in the recent Arctic policy of 2020 (Ministry of Foreign Affairs, 2020). Northern Norway and Svalbard are located in a geopolitically sensitive area; any commercial activity or management interventions in the Barents Sea region have potential implications for strategic and security interests and need to be balanced against larger geopolitical concerns, particularly since the marine space between northern Norway and Svalbard is the only access of the Russian Northern Fleet to the North Atlantic. Furthermore, the ocean area contains important fishing grounds for multiple nations, the seabed is thought to house large reservoirs of oil and gas, and certain aspects of the Svalbard Treaty regarding access to resource exploitation are disputed by several nations (Pedersen, 2008, 2019; Østerud and Hønneland, 2014).

We find very little coverage and elaboration of geopolitically important questions, such as securitization and strategic issues in the daily news coverage of the Helgeland, Lofoten, Vesterålen region and Svalbard.
However, the High North News, which labels itself as an independent news producer with a broader Arctic perspective, clearly has a more strategic perspective in its coverage with considerable emphasis on resource conflicts, securitization, the increasing militarization of the Arctic, and questions regarding international collaboration in the Arctic. One can argue that the government's high North policies promote the view that justice and collaboration and responsible management will solve all challenges. From a political science perspective, this viewpoint rests on a belief in institutionalism, that is, the belief that international relations can be handled through negotiations and agreed upon rules (e.g., Alcantara and Wilson, 2014). Conversely, it negates or suppresses a geopolitical realism perspective in fear of the potential implications (e.g., Guzzini, 2013), namely that the Arctic nations are all part of a power game in which each nation first and foremost seeks to secure their own domestic economic interests. This perspective is mostly lacking in the daily news coverage of the North, but is amply covered in the scientific literature (e.g., Pedersen, 2009; Solli et al., 2013; Østhagen and Raspotnik, 2018).

As mentioned in the introduction, the scientific literature on social, economic, and environmental change in the northern Norwegian coastal regions is quite extensive. Arguably, the government's policies for the northern regions represent a fair coverage of some of the environmental challenges like climate change, but inadequately reflect the social and economic dynamics and problems. This kind of discrepancy between science and policy, where the former tends to emphasize problems and causes, while politicians emphasize judgments and remedies, has also been noted in other research (Trumbo, 1996). Other authors have discussed how central authorities downplay the immense value creation provided by local and traditional sectors like coastal fisheries and nature-based tourism and attempt to paint a picture that people in the northern regions are surviving only because of state subsidies (Aasjord and Hønnerud, 2019). Furthermore, an alliance between the ruling political parties and private sector corporations has for years tried to establish a narrative where the key message is that the future welfare and livelihoods in the North depend on large-scale industrial exploitation of natural resources backed by international investments and ownership (Aasjord and Hønnerud, 2019). 
Our interpretation of this policy framing is that the scientific literature provides a fairly nuanced and diverse perspective of the socio-ecological and sociopolitical context of the northern coastal region. The current value creation from natural resources is formidable, and the potential is even larger. However, there are great dilemmas and conflicts regarding a number of complicated issues such as governance structures and quotas for fishing. Also, the public is divided on oil and gas exploitation versus fishing and tourism, social security is at risk due to declining rural populations, centralization of public services is increasing, certain areas and sectors suffer from high unemployment, and poor health affects some social strata (AMAP, 2017). The scientific literature also demonstrates how future development of livelihoods is a question of policies at different scales. Issues as diverse and different as climate change, industrial exploitation of common property resources by international actors in Arctic waters, governance policies shaped by the Arctic Council, and postcold war militarization of the Arctic all have local-global linkages (Exner-Pirot, 2013).

Moreover, as a recent study showed, scientists and environmental managers can have a perception of drivers of change that differs from both the general public and official policy documents (Kaltenborn et al., 2020b). Notably, this study showed that most professionals working with coastal zone management considered biological and physical drivers of change as negative influences on society and environment, and technology and knowledge as positive drivers of change. And perhaps even more interesting, social and economic drivers of change were seen to have little or even negative impacts on development of the coastal zone (Kaltenborn et al., 2020b). In the present analysis, we find that questions relating to how natural resource exploitation, environmental change, and management are related to topics like national security, public services, social security, and health, are almost nonexistent in the recent media discourses on Norway's northern coastal region.

\section{CONCLUSIONS}

Our analysis of a selection of media postings related to northern Norway and Svalbard suggests that different types of media contribute to an overall narrative of economic development based on different types of natural resource exploitation. This narrative does not fully represent the extent of the social dynamics linked to the natural resources as documented by the scientific literature, and is to some degree biased towards climate change, oil and gas exploration, tourism, and marine harvesting. Important areas like emergency preparedness in a time of rapid environmental change and economic transitions receive comparatively little attention. Issues that also largely depend on the natural capital of the resource base like employment structures, sociodemographic change, public services, health, and geopolitical security are largely absent in this narrative. These topics may well have significant representation in local and other media. However, we ascertain that current media does not to any notable extent link these issues to environmental management and natural resource exploitation. In this respect we portend that the current northern region media discourse on environment and management rests on a narrow and incomplete socioecological and sociopolitical perspective. We do find, however, that the media picture we have examined here spans wider in terms of topics and questions than the official Norwegian policy discourse on the northern regions, and that the media narrative to a greater degree challenges the assumptions for sustainable development in the North than the government policies do.

Mass media coverage of any issue emanates from a social relationship among scientists, policy actors, and the public (Boykoff and Boykoff, 2007). This relationship constitutes a package of information inputs from three sources where journalistic factors like personalization, dramatization, and novelty tend to override norms like authority, credibility, and balance, and ultimately often result in deficient or incomplete information. We contend that the current framing of environmental change in the northern coastal regions of Norway captures only a portion of the socio-ecological dynamics of this region and only to a minimal extent represents an alternative frame to the official policy discourse since important aspects of environmental change and management receive little attention. One obvious recommendation is for the media covering this region to reach out to a wider range of sources, particularly the scientific community, on topics like resource-dependent social change, strategic and geopolitical security, international business development, financing and ownership in the marine resources sector, as well as administrative and public services reform and public health. The scant interaction between popular media and science on Arctic issues is not unique to this region of course, but the potential for improved knowledge gathering is considerable here. In an era of increasing amounts of fake news, distorted political messages, increasing geopolitical tensions, and growing interest in the resource potential of the Arctic, there is ever more need and reason for strengthening the representativeness of the factual knowledge base. Science is competing for attention on most fronts with other communication forms, but on the positive side is the growing number of scientific institutions and programs that employ communication strategies and departments. The science-policy interface in the Arctic is expanding quickly, particularly due to the climate change challenge, which opens a window of opportunities for more extensive dialogue between the science community, popular media, and the public. It is evident that the Arctic science community is one of the most critical actors for addressing the skewness and knowledge gaps characterizing the contemporary Arctic scene. 


\section{ACKNOWLEDGEMENT}

This study was supported by the Norwegian Research Council, grant no. 255783.

\section{REFERENCES}

Aasjord, B., and Hønneland, G. 2019. Nord og ned. Nordområdene som koloni og framtidsversjon. Et debattskrift [North and down - The northern areas as colony and future vision. A debate]. Stamsund: Orkana.

Alcantara, C., and Wilson, G.N. 2014. The dynamics of intrajurisdictional relations in the Inuit regions of the Canadian Arctic: An institutionalist perspective. Regional \& Federal Studies 24(1):43-61. https://doi.org/10.1080/13597566.2013.818981

AMAP (Arctic Monitoring and Assessment Programme). 2017. Snow, water, ice and permafrost in the Arctic (SWIPA) 2017. Oslo, Norway: AMAP. https://www.amap.no/documents/doc/snow-water-ice-andpermafrost-in-the-arctic-swipa-2017/1610

Anderson, A. 2009. Media, politics and climate change: Towards a new research agenda. Sociology Compass 3(2):166-182. https://doi.org/10.1111/j.1751-9020.2008.00188.x

Antilla, L. 2010. Self-censorship and science: A geographical review of media coverage of climate tipping points. Public Understanding of Science 19(2):240-256. https://doi.org/10.1177/0963662508094099

Arbo, P., Iversen, A., Knol, M., Ringholm, T., and Sander, G. 2013. Arctic futures: Conceptualizations and images of a changing Arctic. Polar Geography 36(3):163 - 182. https://doi.org/10.1080/1088937X.2012.724462

Bennett, W.L. 1994. The news about foreign policy. In: Bennett, W.L., and Paletz, D.L., eds. Taken by storm: The media, public opinion, and U.S. foreign policy in the Gulf War. Chicago, Illinois: University of Chicago Press. 12-40.

Boykoff, M.T. 2008. Lost in translation? United States television news coverage of anthropogenic climate change, 1995-2004. Climatic Change 86:1-11. https://doi.org/10.1007/s10584-007-9299-3

Boykoff, M.T., and Boykoff, J.M. 2007. Climate change and journalistic norms: A case-study of US mass-media coverage. Geoforum 38(6):1190-1204. https://doi.org/10.1016/j.geoforum.2007.01.008

Carragee, K., and Roefs, W. 2004. The neglect of power in recent framing research. Journal of Communication 54(2):214-233. https://doi.org/10.1111/j.1460-2466.2004.tb02625.x

Dannevig, H., and Holvelsrud, G.K. 2016. Understanding the need for adaptation in a natural resource dependent community in northern Norway: Issue salience, knowledge and values. Climatic Change 135:261-275. https://doi.org/10.1007/s10584-015-1557-1

Entman, R.M. 1993. Framing: Toward clarification of a fractured paradigm. Journal of Communication 43(4):51 - 58 . https://doi.org/10.1111/j.1460-2466.1993.tb01304.x
Exner-Pirot, H. 2013. What is the Arctic a case of? The Arctic as a regional environmental security complex and the implications for policy. The Polar Journal 3(1):120-135. https://doi.org/10.1080/2154896X.2013.766006

Ford, J.D., and Furgal, C. 2009. Foreword to the special issue: Climate change impacts, adaptation and vulnerability in the Arctic. Polar Research 28(1):1 -9. https://doi.org/10.1111/j.1751-8369.2009.00103.x

Grydehøj, A. 2014. Informal diplomacy in Norway's Svalbard policy: The intersection of local community development and Arctic international relations. Global Change, Peace \& Security 26(1):41-54. https://doi.org/10.1080/14781158.2014.856290

Guzzini, S. 2013. Power, realism and constructivism. London: Routledge. 360 p. https://doi.org/10.4324/9780203071748

Haftendorn, H. 2011. NATO and the Arctic: Is the Atlantic alliance a cold war relic in a peaceful region now faced with non-military challenges? European Security 20(3):337-361. https://doi.org/10.1080/09662839.2011.608352

Haley, S., Klick, M., Szymoniak, N., and Crow, A. 2011. Observing trends and assessing data for Arctic mining. Polar Geography 34(1-2):37-61. https://doi.org/10.1080/1088937X.2011.584449

Hanssen-Bauer, I., Førland, E.J., Hisdal, H., Mayer, S., Sandø, A.B., and Sorteberg, A., eds. 2019. Climate in Svalbard $2100-$ A knowledge base for climate adaptation: NCCS Report no. 1/2019. Oslo: Norwegian Centre for Climate Services.

Herman, E.S., and Chomsky, N. 1988. Manufacturing consent: The political economy of mass media. New York: Pantheon Books.

Holt, D., and Barkemeyer, R. 2012. Media coverage of sustainable development issues - attention cycles or punctuated equilibrium? Sustainable Development 20(1):1-17. https://doi.org/10.1002/sd.460

Hovelsrud, G.K., Poppel, B., van Oort, B., and Reist, J.D. 2011. Arctic societies, cultures and peoples in a changing cryosphere. Ambio 40(1):100-110. https://doi.org/10.1007/s13280-011-0219-4

Kaltenborn, B.P., Linnell, J.D.C., Thomassen, J., and Lindhjem, H. 2017. Complacency or resilience? Perceptions of social and environmental change in Lofoten and Vesterålen in northern Norway. Ocean \& Coastal Management 138:29-37. https://doi.org/10.1016/j.ocecoaman.2017.01.010

Kaltenborn, B.P., Østreng, W., and Hovelsrud, G.K. 2020a. Change will be the constant - Future environmental policy and governance challenges in Svalbard. Polar Geography 43(1):25-45. https://doi.org/10.1080/1088937X.2019.1679269

Kaltenborn, B.P., Wold, L.C., and Rybråten, S. 2020b. Hvorfor og hvordan endres Kyst-Norge. Hva mener fagfolk? [Drivers of change in coastal Norway. The perceptions of experts]. Kart og Plan 80(1):23-40.

https://doi.org/10.18261/issn.2535-6003-2020-01-03

Kristoffersen, B., and Dale, B. 2014. Post petroleum security in Lofoten: How identity matters. Arctic Review on Law and Politics 5(2):201-226. 
Lazer, D.M.J., Baum, M.A., Benkler, Y., Berinsky, A.J., Greenhill, K.M., Menczer, F., Metzger, M.J., et al. 2018. The science of fake news. Science 359(6380):1094-1096. https://doi.org/10.1126/science.aao2998

Matthes, J. 2009. What's in a frame? A content analyses of media framing studies in the world's leading communication journals, 1990-2005. Journalism \& Mass Communication Quarterly 86(2):349-367. https://doi.org/10.1177/107769900908600206

Ministry of Foreign Affairs. 2014. Nordkloden: Verdiskaping og ressurser. Klimaendringer og kunnskap. Utviklingen nord på kloden angår oss alle. Nordområdene statusrapport [The northern globe: Value creation and resources. Climate change and knowledge. The development in the north concerns us all]. Oslo: Utenriksdepartementet.

___ 2020. The Norwegian Government's Arctic policy: People, opportunities and Norwegian interest in the Arctic. Oslo: Ministry of Foreign Affairs.

https://www.regjeringen.no/en/dokumenter/arctic_policy/ id2830120/

Misund, O.A., and Olsen, E. 2013. Lofoten - Vesterålen: For cod and cod fisheries, but not for oil? ICES Journal of Marine Science 70(4):722-725.

https://doi.org/10.1093/icesjms/fst086

Noble, B., Ketilson, S., Aitken, A., and Poelzer, G. 2013. Strategic environmental assessment opportunities and risks for Arctic offshore energy planning and development. Marine Policy 39:296-302.

https://doi.org/10.1016/j.marpol.2012.12.011

Olausson, U. Global warming-global responsibility? 2009. Media frames of collective action and scientific certainty. Public Understanding of Science 18(4):421 - 436. https://doi.org/10.1177/0963662507081242

Østerud, Ø., and Hønneland, G. 2014. Geopolitics and international governance in the Arctic. Arctic Review on Law and Politics 5(2):156- 176 .

Østhagen, A., and Raspotnik, A. 2018. Crab! How a dispute over snow crab became a diplomatic headache between Norway and the EU. Marine Policy 98:58-64. https://doi.org/10.1016/j.marpol.2018.09.007

Padrtova, B. 2019. Frozen narratives: How media present security in the Arctic. Polar Science 21:37-46. https://doi.org/10.1016/j.polar.2019.05.006
Pan, Z., and Kosicki, G.M. 1993. Framing analysis: An approach to news discourse. Political Communication 10(1):55-75. https://doi.org/10.1080/10584609.1993.9962963

Pedersen, T. 2009. Norway's rule on Svalbard: Tightening the grip on the Arctic islands. Polar Record 45(2):147-152. https://doi.org/10.1017/S0032247408007973

___ 2019. Polar research and the secrets of the Arctic. Arctic Review on Law and Politics 10:103-129. https://doi.org/10.23865/arctic.v10.1501

Reed, M.S., Graves, A., Dandy, N., Posthumus, H., Hubacek, K., Morris, J., Prell, C., Quinn, C.H., and Stringer, L.C. 2009. Who's in and why? A typology of stakeholder analysis methods for natural resource management. Journal of Environmental Management 90(5):1933 - 1949. https://doi.org/10.1016/j.jenvman.2009.01.001

Reese, S.D. 2007. The framing project: A bridging model for media research revisited. Journal of Communication 57(1):148-154. https://doi.org/10.1111/j.1460-2466.2006.00334.x

Schmidt, A., Ivanova, A. and Schäfer, M.S. 2013. Media attention for climate change around the world: A comparative analysis of newspaper coverage in 27 countries. Global Environmental Change 23(5):1233-1248. https://doi.org/10.1016/j.gloenvcha.2013.07.020

Semetko, H.A., and Valkenburg, P.M. 2000. Framing European politics: A content analysis of press and television news. Journal of Communication 50(2):93-109. https://doi.org/10.1111/j.1460-2466.2000.tb02843.x

Solli, P.E., Rowe, E.W., and Lindgren, W.Y. 2013. Coming into the cold: Asia's Arctic interests. Polar Geography 36(4):253-270. https://doi.org/10.1080/1088937X.2013.825345

Stieglitz, S., Mirbabaie, M., Ross, B., and Neuberger, C. 2018. Social media analytics - Challenges in topic discovery, data collection, and data preparation. International Journal of Information Management 39:156-168. https://doi.org/10.1016/j.ijinfomgt.2017.12.002

Trumbo, C. 1996. Constructing climate change: Claims and frames in US news coverage of an environmental issue. Public Understanding of Science 5(3):269-283.

https://doi.org/10.1088/0963-6625/5/3/006

Vaismoradi, M., Turunen, H., and Bondas, T. 2013. Content analysis and thematic analysis: Implications for conducting a qualitative descriptive study. Nursing \& Health Sciences 15(3):398-405.

https://doi.org/10.1111/nhs.12048 